\title{
Characterization of the Autolytic Enzymes of Clostridium perfringens
}

\author{
By RUSSELL WILLIAMSON AND J. BARRIE WARD \\ Division of Microbiology, National Institute for Medical Research, \\ Mill Hill, London NW7 1 AA
}

(Received 8 February 1979)

Clostridium perfringens and isolated walls of this organism autolysed rapidly when incubated in buffer at $\mathrm{pH} \mathrm{7.0} \mathrm{with} \mathrm{the} \mathrm{release} \mathrm{of} \mathrm{free-reducing} \mathrm{groups} \mathrm{but} \mathrm{no} \mathrm{N}$-terminal amino acids. The predominant autolytic enzyme was an endo- $\beta$ - $N$-acetylglucosaminidase, and an endo- $\beta$ - $N$-acetylmuramidase was also present. The autolytic enzymes could be solubilized by extraction of the organisms with $5 \mathrm{M}-\mathrm{LiCl}$ and would then subsequently bind to and rapidly lyse walls of Micrococcus luteus and, more slowly, formamide-extracted walls of $C$. perfringens and walls of Bacillus subtilis. Lysis of $C$. perfringens walls by these extracted enzymes could not be demonstrated.

\section{INTRODUCTION}

The bacterial wall consists of a cross-linked insoluble heteropolymer which completely encloses the organism. During growth there is a requirement for expansion of the wall and such modification of the components that will allow subsequent division of the parent organism into two new individuals. Autolytic enzymes (autolysins) have long been considered as candidates for such a role although there is little direct supportive evidence available (for review, see Rogers, 1979). In clostridia, particularly Clostridium botulinum, autolytic activity has been implicated in the release of toxin (Boroff, 1955; Bonventre \& Kempe, 1960).

Previous studies with $C$. perfringens BP6KA (Tinelli, 1968) indicated that this organism did not autolyse, whereas autolysis of several other clostridia was observed. In contrast, Kawata \& Takumi (1970) found that $C$. perfringens S114-3 underwent autolysis and that dissolution of the wall was accompanied by the release of free amino groups, although the nature of the autolytic activity or activities involved was not determined. The present work was undertaken to study autolysis in $C$. perfringens NCTC 8237, the type-strain of $C$. perfringens (C. welchii) type $\mathrm{A}$, and to characterize the enzymes involved in the process.

\section{METHODS}

Cultural conditions. Clostridium perfringens NCTC 8237 was grown at $35^{\circ} \mathrm{C}$ without shaking in Erlenmeyer flasks filled with medium of the following composition (in $\mathrm{g}^{-1}$ ): Casamino acids (Difco), 10; yeast extract (Difco), $10 ; \mathrm{KH}_{2} \mathrm{PO}_{4}, 2 \cdot 7$; glucose, 4 ; to which was added thioglycollic acid (1 mM) and a salts solution (Pollock, 1965) $\left(1 \mathrm{ml} \mathrm{l}^{-1}\right)$.

Measurement of autolytic activity. Lysis of whole organisms was measured by resuspending washed bacteria in $50 \mathrm{~mm}$-Tris/ $\mathrm{HCl}$ buffer $\mathrm{pH} 7.0$ containing $0.2 \mathrm{mM}$-phenylmethylsulphonyl fluoride (Tris-PMSF buffer) at $37^{\circ} \mathrm{C}$ and following the decrease in turbidity at $600 \mathrm{~nm}$. Autolytic wall preparations (walls containing bound autolytic enzymes) were resuspended in similar buffer and the turbidity decrease was followed at $380 \mathrm{~nm}$.

Extraction of autolytic enzymes. The method used was based on that of Brown (1972). Organisms in the exponential phase of growth $\left(A_{600} 1.6\right.$ to 1.8$)$ were harvested by centrifuging $\left(12000 \mathrm{~g}\right.$ for $5 \mathrm{~min}$ at $\left.4{ }^{\circ} \mathrm{C}\right)$, washed with water and then freeze-dried or, if they were to be used immediately, they were washed and prepared as a paste. In either case the bacteria were extracted with $5 \mathrm{M}-\mathrm{LiCl}$ at $0{ }^{\circ} \mathrm{C}$ for 30 to $60 \mathrm{~min}$, after 
which the organisms were removed by centrifuging. The concentration of bacteria used was $50 \mathrm{mg}$ dry wt $\mathrm{ml}^{-1}$ for freeze-dried preparations and approximately $250 \mathrm{mg}$ wet $\mathrm{wt} \mathrm{ml}^{-1}$ for cell pastes. The $\mathrm{LiCl}$ extracts containing released autolytic enzymes were then diluted and bound to wall preparations as described by Brown (1972).

Preparation of walls containing autolysin (autolytic walls). Cultures in the exponential phase of growth were cooled rapidly by the addition of ice to minimize autolysis and then harvested by centrifuging as described above. All subsequent operations were carried out at 0 to $4{ }^{\circ} \mathrm{C}$. The bacteria were washed with Tris-PMSF buffer, resuspended in similar buffer and then disrupted by passage through an Aminco-French pressure cell. Unbroken organisms were removed by centrifuging (1000 $\mathrm{g}$ for $10 \mathrm{~min}$ ) and the walls were recovered from the supernatant by further centrifuging $(27000 \mathrm{~g}$ for $10 \mathrm{~min})$. After washing once with buffer and twice with water, the walls were freeze-dried and stored at $-20{ }^{\circ} \mathrm{C}$.

Preparation of detergent- and formamide-treated walls. Walls treated with hot detergent (sodium dodecyl sulphate, SDS) to inactivate and extract associated autolytic enzymes were prepared from $C$. perfringens, Bacillus subtilis 168 and Micrococcus luteus as described by Fein \& Rogers (1976). Clostridial walls were also treated with formamide at $160^{\circ} \mathrm{C}$ as described by Pickering (1966) to extract secondary wall polymers.

Characterization of free-reducing groups. Samples of walls and autolysed material containing 5 to $20 \mu \mathrm{mol}$ hexosamine were reduced with $\mathrm{KB}^{3} \mathrm{H}_{4}\left(11.3 \mathrm{mCi} \mathrm{mmol}^{-1}, 50 \mathrm{~mm}\right.$ in $\left.5 \mathrm{~mm}-\mathrm{KOH}\right)$ overnight at $2{ }^{\circ} \mathrm{C}$. Excess reagent was destroyed by addition of acid and the reduced material was then hydrolysed $\left(4 \mathrm{M}-\mathrm{HCl}\right.$ at $100{ }^{\circ} \mathrm{C}$ for $4 \mathrm{~h}$ ). After removal of the acid by repeated evaporation of water in vacuo over $\mathrm{NaOH}$, the hydrolysates were chromatographed on columns $(0.9 \times 22 \mathrm{~cm})$ of Dowex 50 equilibrated with $0.1 \mathrm{M}$-pyridine/acetate buffer pH $2 \cdot 8$ (Hughes, 1970; Ward, 1973). Muramic acid and $\left[{ }^{3} \mathrm{H}\right]$ muramitol were eluted with this buffer. Appropriate fractions were pooled and, after removal of buffer salts by repeated evaporation of water, they were further purified by chromatography on Whatman no. 3 paper in butan-1-ol/acetic acid/water $(3: 1: 1$, by vol.) The other hexosamines and $\left[{ }^{3} \mathrm{H}\right]$ hexosaminols which did not completely separate were eluted from the column with $0.133 \mathrm{M}$-pyridine/acetate buffer $\mathrm{pH} 3.85$. After removal of buffer salts as described above, they were $\mathrm{N}$-acetylated and $\mathrm{N}$-acetylhexosamines were separated from $\mathrm{N}$-acetyl- $\left[{ }^{3} \mathrm{H}\right]$ hexosaminols by electrophoresis in $60 \mathrm{~mm}$-sodium tetraborate $/ \mathrm{NaOH}$ buffer $\mathrm{pH} 9.5$ at $80 \mathrm{~V} \mathrm{~cm}^{-1}$ for $2 \mathrm{~h}$ (Crumpton, 1959; Takasaki \& Kobata, 1974). The $\mathrm{N}$-acetyl- $\left[{ }^{3} \mathrm{H}\right]$ hexosaminols were deacylated in $1 \mathrm{M}-\mathrm{HCl}$ at $100{ }^{\circ} \mathrm{C}$ for $1 \mathrm{~h}$ and the $\left[{ }^{3} \mathrm{H}\right.$ ]hexosaminols were subjected to electrophoresis in $60 \mathrm{~mm}$-borate buffer $\mathrm{pH} 7.5$ at $80 \mathrm{~V} \mathrm{~cm}^{-1}$ for $4 \mathrm{~h}$ to separate $\left[{ }^{3} \mathrm{H}\right]$ galactosaminol from $\left[{ }^{3} \mathrm{H}\right]$ glucosaminol and $\left[{ }^{3} \mathrm{H}\right]$ mannosaminol. The latter were finally separated after $N$-acetylation by chromatography on DEAE-cellulose paper (Whatman DE20) in ethyl acetate/pyridine/5 mm-boric acid (3:2:1, by vol.) as described by Conrad (1976). Recoveries of individual components during this procedure were determined by the addition of $\left[{ }^{14} \mathrm{C}\right]$ glucosamine $(0 \cdot 01 \mu \mathrm{Ci})$ to the initial samples of wall and autolysed material and ranged from 64 to $78 \%$ overall.

Analytical methods. Hexosamines were measured after hydrolysis $\left(4 \mathrm{M}-\mathrm{HCl}\right.$ at $100{ }^{\circ} \mathrm{C}$ for $\left.4 \mathrm{~h}\right)$ by the method of Levvy \& McAllan (1959) using glucosamine as the standard or on an amino acid analyser. Reducing groups produced during autolysis were determined by the Thompson \& Shockman (1968) modification of the method of Park \& Johnson, again using glucosamine as the standard. The release of free amino groups was assayed as described by Forsberg \& Ward (1972). Soluble products isolated from autolysates were examined for chromagen production in the Morgan-Elson assay and for reducing groups as described by Ghuysen et al. (1966) and Ashwell (1957), respectively, using $N$-acetylglucosamine as the standard. Where appropriate, samples of these soluble products were reduced with $50 \mathrm{~mm}^{-} \mathrm{KBH}_{4}$ for $6 \mathrm{~h}$ at $4{ }^{\circ} \mathrm{C}$. Phosphate was measured by the method of Ames \& Dubin (1960). $N$-Acetylhexosamines on chromatograms or after electrophoresis were detected by the method of Partridge (1948).

Radioactivity on chromatograms or after electrophoresis was located using a Packard 7201 radiochromatogram scanner. Radioactivity on paper or in aqueous solutions was measured as described previously (Wyke $\&$ Ward, 1977) with differential counting efficiencies of $38.6 \%$ for ${ }^{3} \mathrm{H}$ and $46.5 \%$ for ${ }^{14} \mathrm{C}$ in liquid and $5.9 \%$ for ${ }^{3} \mathrm{H}$ and $48 \cdot 1 \%$ for ${ }^{14} \mathrm{C}$ on paper.

\section{RESULTS AND DISCUSSION}

\section{Autolysis of C. perfringens}

In Tris-PMSF buffer at $37^{\circ} \mathrm{C}$ the maximum rate of autolysis of both $C$. perfringens and autolytic walls occurred at $\mathrm{pH} 7.0$ and at an ionic strength of $0.05 \mathrm{M}$. Under these conditions $C$. perfringens, harvested in the late-exponential phase of growth, showed a decrease in turbidity of $75.1 \%$ in $60 \mathrm{~min}$. However, the rate did not differ greatly over a pH range of 6 to 8 and ionic strengths of 0.01 to $0.2 \mathrm{M}$. Autolysis of the walls was accompanied by a large increase in the reducing power of the suspension but with no concomitant increase in the 


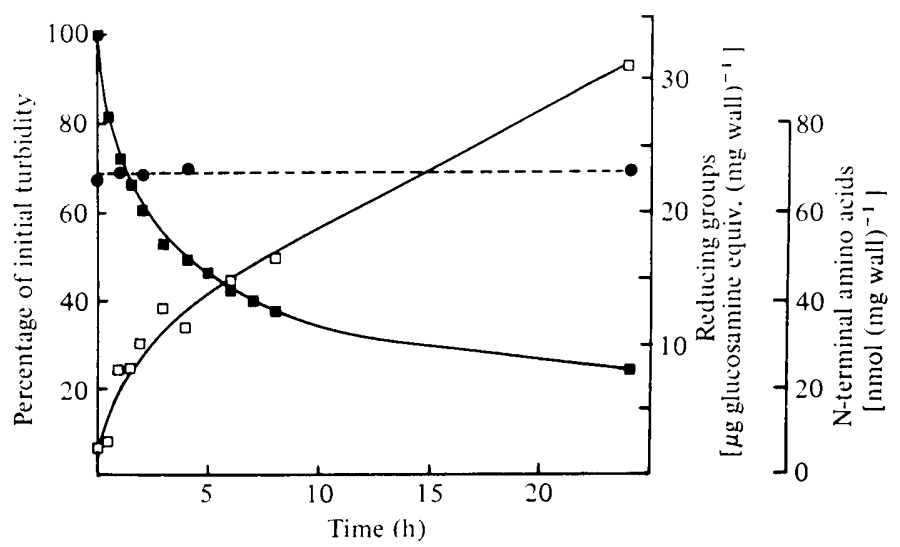

Fig. 1. Autolysis of $C$. perfringens walls. Walls $\left(1 \mathrm{mg} \mathrm{ml} \mathrm{l}^{-1}\right)$ were resuspended in buffer at $37^{\circ} \mathrm{C}$ and the decrease in turbidity followed at $380 \mathrm{~nm}(\square)$. Samples were assayed at intervals for reducing power $(\square)$ and $\mathrm{N}$-terminal amino groups $(\mathbf{O})$.

number of free amino groups present (Fig. 1). Thus lysis appeared to result from the action of a glycosidase(s) and not from either $N$-acetylmuramoyl-L-alanine amidase or endopeptidase activities. This finding contrasts with the reports on the nature of autolytic enzymes in C. perfringens S114-3 (Kawata \& Takumi, 1970), C. tetani (Tinelli, 1968) and C. botulinum type A (Kawata \& Takumi, 1971) where free amino groups were produced; although subsequently Takumi et al. (1971) described an endo- $\beta$ - $N$-acetylglucosaminidase as the second autolytic enzyme of $C$. botulinum.

\section{Lysis of walls by extracted autolytic enzymes}

Initial attempts to extract the autolytic enzyme(s) of $C$. perfringens using either $5 \mathrm{M}-\mathrm{LiCl}$ (Brown, 1972) or $10 \mathrm{~mm}-\mathrm{NaOH}$ containing bovine serum albumin (Coyette \& Ghuysen, 1970) appeared unsuccessful. No autolytic activity against SDS-inactivated walls of $C$. perfringens could be detected in the extracts. However, Pickering (1966) had shown that isolated walls of $C$. perfringens were resistant to lysozyme and that this resistance could be overcome by partial removal of secondary polymers by treatment of the walls with hot formamide. Using walls treated in this way, from which $39.2 \%$ of the phosphate had been removed, the $5 \mathrm{M}-\mathrm{LiCl}$ extracts of $C$. perfringens were found to contain lytic enzymes. Maximum binding of these enzymes to the formamide-extracted walls occurred in the presence of $250 \mathrm{~mm}-\mathrm{LiCl}$. When autolytic enzymes extracted from $C$. perfringens (approximately $10 \mathrm{mg}$ dry wt) were bound to treated walls $(2 \mathrm{mg})$ at $0{ }^{\circ} \mathrm{C}$ and the walls were subsequently incubated at $37{ }^{\circ} \mathrm{C}$, the turbidity of the suspension decreased by $33 \%$ in $5 \mathrm{~h}$. Under identical conditions walls of $M$. luteus and $B$. subtilis showed decreases in turbidity of $74.4 \%$ and $22.4 \%$, respectively. Thus the walls of $M$. luteus are an excellent substrate for the autolytic glycosidase(s) of $C$. perfringens, as they are for numerous lysozymes $(N$-acetylmuramidases) and the endo- $\beta-N$-acetylglucosaminidase of $B$. subtilis (Fan \& Beckman, 1973). This finding clearly distinguishes the autolytic glycosidases described in the present study from the lytic enzyme found as a contaminant of phospholipase $\mathrm{C}$ preparations from C. perfringens (Martin \& Kemper, 1970). This latter enzyme hydrolysed the peptidoglycan (murein) of Escherichia coli but had no demonstrable activity on walls of $M$. luteus and Sarcina lutea; although, as shown below and by Martin \& Kemper (1970), both lytic activities involve an endo- $\beta$ - $N$-acetylglucosaminidase.

The reasons why inactivated walls of $C$. perfringens are resistant to the organisms own autolytic enzymes remain unclear. Although many other examples of walls being resistant to 
Table 1. Proportions of hexosamines obtained from reduced C. perfringens walls and the products of autolysis

\begin{tabular}{|c|c|c|c|c|c|c|}
\hline \multirow[b]{2}{*}{ Sample } & \multicolumn{5}{|c|}{ Hexosamine (molar proportion to muramic acid) } & \multirow{2}{*}{$\begin{array}{l}\text { Average } \\
\text { glycan } \\
\text { chain } \\
\text { length } \\
\text { (disac- } \\
\text { charides) } \dagger\end{array}$} \\
\hline & Muramitol & $\begin{array}{l}\text { Glucos- } \\
\text { amine }\end{array}$ & $\begin{array}{l}\text { Glucos- } \\
\text { aminol }\end{array}$ & $\begin{array}{l}\text { Galactos- } \\
\text { amine }\end{array}$ & $\begin{array}{l}\text { Mannos- } \\
\text { amine }\end{array}$ & \\
\hline Non-autolysed walls & 0.017 & $1 \cdot 261$ & 0.073 & $0 \cdot 264$ & $1 \cdot 229$ & $11 \cdot 3$ \\
\hline Residual walls* & 0.032 & $1 \cdot 304$ & $0 \cdot 145$ & 0.751 & $1 \cdot 844$ & $5 \cdot 8$ \\
\hline Soluble products* & 0.069 & 0.214 & 0.849 & 0.216 & 0.867 & $1 \cdot 2$ \\
\hline
\end{tabular}

* Walls were incubated in Tris-PMSF buffer at $37^{\circ} \mathrm{C}$ for $48 \mathrm{~h}$ and then the residual walls were separated from the soluble products by centrifuging $(27000 \mathrm{~g}, 10 \mathrm{~min})$.

$\dagger$ Calculated from the ratio of free-reducing groups (as muramitol and glucosaminol) to the total amount of muramic acid present.

hydrolysis by lysozyme are known, in most cases where autolysins have been investigated they appear to attack parental walls. Possibly in $C$. perfringens the complex secondary polymers present mask the peptidoglycan after wall isolation and thus prevent association of the extracted autolytic enzymes with their binding sites on the peptidoglycan.

\section{Characterization of the glycosidases}

To determine the nature of the autolytic glycosidase(s), samples of walls, autolysed residual walls and soluble products were reduced with $\mathrm{KB}^{3} \mathrm{H}_{4}$ to label the free-reducing groups present. The reduced samples were then hydrolysed and after chromatography on Dowex 50 the proportions of the various hexosamines and $\left[{ }^{3} \mathrm{H}\right]$ hexosaminols were determined (Table 1). The walls contained a molar excess of both glucosamine and mannosamine with less galactosamine relative to the amount of muramic acid present. These hexosamines are known to be components of the secondary polymers present in the wall of $C$. perfringens (Pickering, 1966) whereas muramic acid is found only in peptidoglycan. After reduction, radioactivity was found chiefly as $\left[{ }^{3} \mathrm{H}\right]$ muramitol and $\left[{ }^{3} \mathrm{H}\right]$ glucosaminol; other hexosaminols were present only in trace amounts. The average length of the glycan chains in the peptidoglycan of the isolated walls was $11 \cdot 3$ disaccharides. This value was calculated from the ratio of the free-reducing groups present in both muramic acid and glucosamine to the total amount of muramic acid present. After autolysis for $48 \mathrm{~h}$, the total free-reducing groups present had increased 6-fold and 13-fold for muramic acid and glucosamine, respectively, in the residual walls and the soluble products. At this time the average length of glycan chains found in the residual walls was 5.8 disaccharides whereas the glycan released as soluble products was only 1.2 disaccharides in length. These results suggest the presence of both $N$-acetylmuramidase and $N$-acetylglucosaminidase activities. Free-reducing groups of muramic acid have been found in walls of Bacillus licheniformis, B. subtilis and Staphylococcus aureus, organisms apparently lacking $N$-acetylmuramidase activity among their autolysins. In these organisms the reducing muramic acid residues are thought to arise during biosynthesis of peptidoglycan (Ward, 1973). Moreover, in contrast to the present results, autolysis of walls prepared from the bacilli does not lead to any increase in the number of free-reducing groups of muramic acid present (C. W. Forsberg \& J. B. Ward, unpublished observations).

Even after autolysis of clostridial walls had been allowed to proceed for $48 \mathrm{~h}$, the soluble products obtained by centrifuging represented only $53 \%$ of the dry weight of the original walls. Analysis of the residual material showed it to contain the bulk of the secondary polymers together with a small amount of peptidoglycan. In this respect $C$. perfringens differs from the majority of other organisms examined where autolytic enzymes solubilize virtually all of the wall without total degradation of the peptidoglycan. 


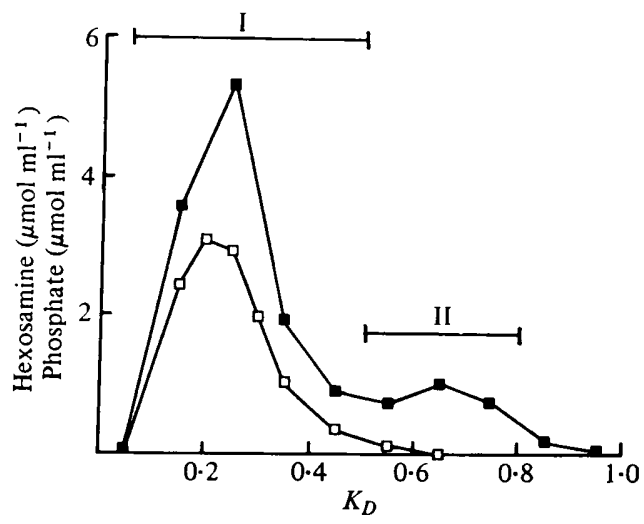

Fig. 2. Fractionation of the soluble products from autolysed $C$. perfringens walls. Soluble products obtained by centrifuging were chromatographed on a column $(1.6 \times 39 \mathrm{~cm})$ of Sephadex G-25 and eluted with distilled water. Fractions $(2 \mathrm{ml})$ were collected and samples were assayed for hexosamine $(\square)$ and phosphate ( $\square$ ). Appropriate fractions were pooled as indicated.

Chromatography of the soluble products on Sephadex G-25 gave two peaks of material containing hexosamine (Fig. 2). That of lower molecular weight (peak II) contained little phosphate, suggesting that this material was derived predominantly from peptidoglycan. Peak I contained phosphate and large amounts of glucosamine, galactosamine and mannosamine together with smaller amounts of muramic acid, suggesting that this material was mainly solubilized secondary polymers with associated peptidoglycan. After treatment of material from peak II with $\mathrm{KBH}_{4}$, more than $95 \%$ of the glucosamine present was reduced whereas only $12 \%$ of the muramoyl residues were found as muramitol. Thus the glycan in this peak appeared to be present mainly as disaccharides. This was confirmed by estimation of the reducing power. Moreover, the formation of chromagen when unhydrolysed material was tested in the Morgan-Elson reaction suggests that the major disaccharide present is $N$-acetylmuramoyl- $N$-acetylglucosamine. Glucosamine itself does not form a chromogen in this reaction (Morgan \& Elson, 1934) and therefore a disaccharide with a reducing glucosamine residue would also be unlikely to react.

$N$-Acetylhexosamines were not detected in the products derived from autolysed walls suggesting that exo- $N$-acetylhexosaminidases are not active during autolysis. Such enzymes could release non-reducing terminal $N$-acetylhexosamine residues from either glycan or the soluble products derived by the action of the autolytic glycosidases.

Similar results were obtained using autolytic enzymes extracted with $5 \mathrm{M}-\mathrm{LiCl}$ and bound to walls of either $C$. perfringens (formamide-extracted) or $M$. luteus. In the latter case, the resulting soluble products again contained free-reducing groups of glucosamine $(59.8 \%$ of the total glucosamine present) and of muramic acid ( $8.9 \%)$. These results indicate that both glycosidases observed in autolysis of $C$. perfringens walls can be extracted using high concentrations of salt and can bind to and are active during the lysis of $M$. luteus walls. Moreover, the proportions of the two activities found in the two systems are similar.

Thus the major autolytic enzyme of $C$. perfringens is an endo- $N$-acetylglucosaminidase which on prolonged incubation hydrolyses a significant amount of the glycan of the clostridial wall to disaccharides. Associated with this is an endo- $N$-acetylmuramidase activity. The possibility remains that the observed muramidase activity is due to a lack of specificity of the glucosaminidase, a question that might only be resolved by the isolation and separation of the two enzymes.

We wish to thank Professor H. J. Rogers for his continued interest, and one of us (R.W.) acknowledges receipt of an MRC research studentship. 


\section{REFERENCES}

Ames, B. N. \& Dubin, D. T. (1960). The role of polyamines in the neutralisation of bacteriophage deoxyribonucleic acid. Journal of Biological Chemistry 235, 769-775.

AshWELL, G. (1957). Colorimetric analysis of sugars. Methods in Enzymology 3, 73-105.

Bonventre, R. F. \& Kempe, L. L. (1960). Physiology of toxin production by Clostridium botulinum types A and B. I. Growth, autolysis and toxin production. Journal of Bacteriology 79, 18-23.

Boroff, D. A. (1955). Study of toxins of Clostridium botulinum. III. Relation of autolysis to toxin production. Journal of Bacteriology 70, 363-367.

Brown, W. C. (1972). Binding and release from cell walls: a unique approach to the purification of autolysins. Biochemical and Biophysical Research Communications 47, 993-996.

ConRad, H. E. (1976). Radiochromatographic analysis of reducing carbohydrates by radiochromatography. Methods in Carbohydrate Chemistry 7, 71-75.

Coyette, J. \& Ghuysen, J.-M. (1970). Wall autolysin of Lactobacillus acidophilus strain 63 AM Gasser. Biochemistry 9, 2952-2956.

Crumpton, M. J. (1959). Identification of amino sugars. Biochemical Journal 72, 479-486.

FAN, D. P. \& Reckman, M. M. (1973). Micrococcus lysodeikticus bacterial walls as a substrate specific for the autolytic glycosidase of Bacillus subtilis. Journal of Bacteriology 114, 804-813.

FeIN, J. \& Rogers, H. J. (1976). Autolytic-enzyme deficient mutants of Bacillus subtilis 168. Journal of Bacteriology 127, 1427-1442.

ForsberG, C. W. \& WARD, J. B. (1972). N-Acetylmuramyl-L-alanine amidase of Bacillus licheniformis and its L-form. Journal of Bacteriology 110 , 878-888.

Ghuysen, J.-M., Tipper, D. J. \& Strominger, J. L. (1966). Enzymes that degrade bacterial cell walls. Methods in Enzymology 8, 685-699.

Hughes, R. C. (1970). Autolysis of isolated cell walls of Bacillus licheniformis NCTC 6346 and Bacillus subtilis Marburg strain 168. Biochemical Journal 119, 849-860.

KaWATA, T. \& TAKUMI, K. (1970). Initiation sites of autolysis in Clostridium perfringens Type $\mathrm{A}$ as revealed by electron microscopy. Journal of General and Applied Microbiology 16, 341-345.

KaWaTA, T. \& Takumi, K. (1971). Autolytic enzyme system of Clostridium botulinum. I. Partial purification and characterisation of an autolysin of Clostridium botulinum Type A. Japanese Journal of Microbiology 15, 1-10.
Levvy, G. A. \& MCAllan, A. (1959). The Nacetylation and estimation of hexosamines. Biochemical Journal 73, 127-132.

Martin, H. H. \& Kemper, S. (1970). Endo- $N$ acetylglucosaminidase from Clostridium perfringens lytic for cell wall murein of Gram-negative bacteria. Journal of Bacteriology 102, 347-350.

Morgan, W. J. T. \& Elson, L. A. (1934). A colorimetric determination of $\mathrm{N}$-acetylglucosamine and $\mathrm{N}$-acetylchondrosamine. Biochemical Journal 28, 988-995.

PARTRIDGE, S. M. (1948). Filter-paper partition chromatography of sugars. Biochemical Journal 42, 238-250.

Pickering, B. T. (1966). Components of the cell wall of Clostridium welchii (type A). Biochemical Journal 100, 430-440.

Pollock, M. R. (1965). Purification and properties of penicillinases from two strains of Bacillus licheniformis: a chemical, physicochemical and physiological comparison. Biochemical Journal 94, 666-675.

Rogers, H. J. (1979). The function of bacterial autolysins. In Microbial Polysaccharides and Polysaccharases (in the Press). Edited by R. C. W. Berkeley, G. W. Gooday \& D. C. Ellwood. London: Academic Press.

TAKASAKI, S. \& KobATA, A. (1974). Microdetermination of individual neutral and amino sugars and $\mathrm{N}$-acetylneuraminic acid in complex saccharides. Journal of Biochemistry 76, 783-789.

Takumi, K., Kawata, T. \& Hisatsune, K. (1971). Autolytic enzyme system of Clostridium botulinum. II. Mode of action of autolytic enzymes in Clostridium botulinum Type A. Japanese Journal of Microbiology 15, 131-141.

Thompson, J.S. \& Shockman, G. D. (1968). A modification of the Park and Johnson reducing sugar determination suitable for the assay of insoluble materials; its application to bacterial cell walls. Analytical Biochemistry 22, 260-268.

TINELLI, R. (1968). Mise en évidence d'enzyme autolytiques dans les parois de différents sporulales. Comptes rendus hebdomadaire des séances de l'Académie des sciences 266, 1792-1795.

WARD, J. B. (1973). The chain length of glycans in bacterial walls. Biochemical Journal 133, 395-398.

WYKE, A. W. \& WARD, J. B. (1977). Biosynthesis of wall polymers in Bacillus subtilis. Journal of Bacteriology 130, 1055-1063. 